\title{
ベクトルレーダによる地形適応走査時の地中レーダ信号処理*
}

\author{
川合康 弘 ${ }^{* 1}$, 長谷川泰久*2, 佐藤 慎 祐*1 \\ Zakarya ZYADA*1, 松野隆幸*3, 福田敏男*3
}

\section{GPR Signal Processing on Geography Adaptive Scanning with Vector Radar}

\author{
Yasuhiro KAWAI, Yasuhisa HASEGAWA, Shinsuke SATO, \\ Zakarya ZYADA, Takayuki MATSUMOTO and Toshio FUKUDA*4 \\ ${ }^{* 4}$ Department of Micro-Nano Systems Engineering, Nagoya University, \\ Furo-cho, Chikusa-ku, Nagoya-shi, Aichi, 464-8603 Japan
}

\begin{abstract}
Ground Penetrating Radar (GPR) is a promissing sensor for landmine detection, however there are two major problems to overcome: One is the non-planer (e.g. rough and/or undulating) ground surface. It remains unremovable clutters on a sub-surface image output from GPR. Geography adaptive scanning is useful to image objects beneath non-planer ground surface. The other problem is the distance between the antennas of GPR. When imaging the small objects such as an antipersonnel landmine buried in shallow depth, it increases the nonlinearity of the relationship between the time for propagation and the depth of a buried object. In this paper, we modify Kirchoff migration so as to account for not only the variation of height and pose of the sensor head, but also the antennas alignment of the vector radar. The validity of this method is discussed through application to the signals acquired in experiments.
\end{abstract}

Key Words : Landmine Detection, GPR, Signal Processing, Migration

\section{1.は じめに}

現在，世界には 7000 万個の埋設地雷が未処理で放 置されているといわれており, 重大な社会問題になっ ている(1). 現時点で作業者にもっとも信頼されている のは挆針と金属探知機であるが,この二つにも問題が ある(2). 探針は，作業者がかなり地雷に接近する必要 があること，また地雷と物理的に接触する必要がある ことから, 危険性が非常に大きい. 金属探知機は, 近 年のプラスチック製対人地雷の普及により，その効果 が薄れてきている.プラスチック製地雷も信管などに わずかな金属を含むため，探知できないわけではない が，地雷原に散在する弾丸の破片など地雷以外の小金 属片などとの識別はきわめて困難であり，探知の効率 を害している。

一方，地中レーダ (Ground Penetrating Radar：GPR) は，金属探知機の代替あるいは補助として，最も期待 されているセンサである(1)(2). 地中レーダは電磁波の

\footnotetext{
*原稿受付 2006 年 1 月 20 日.

*1 名古屋大学大学院工学研究科 (画 464-8603 名古屋市千種区 不老町).

*2 正員, 筑波大学大学院システム情報工学研究科(画 305-8577 つくば市天王台 1-1-1).

*3 正員, 名古屋大学大学院工学研究科.

E-mail : fukuda@mein.nagoya-u.ac.jp
}

反射を利用したセンサで，もともとは遺跡探査や地中 埋設管探知, コンクリート内の鉄筋や欠陥探知に用い られてきた. 探針を使った探知のように地雷に直接接 触する必要はなく，また金属探知機と違いプラスチッ ク製地雷に対しても有効である. さらに，埋設物の哚 さや形状に関する情報を得ることもできる. 地雷探知 にもきわめて有効と考えられており，研究事例も多い (9).

このように高い期待がもたれている地中レーダであ るが, それ単体では問題も多い. まず, (1)地雷が埋設 されている土㙴の状態, 特に水分によって電磁波の減 衰が大きくなり，性能が悪化する，また，(2) 不均質な 土境を調べるときにも, 探知結果の信頼性が低下する. さらに大きな問題として, (3) 地面に凹凸や傾斜があ るときには，それらが探査結果の像に写りこみ，地表 面付近の埋設物を判別することが難しくなる．最初の 問題に関しては, 水分に影響されにくい周波数を選択 することで, 2 番目の問題に対しては金属探知機との 併用によってある程度緩和することができるが，最後 の問題は, 金属探知機との相乗効果が期待できる深さ での信頼性低下であり，看過できない問題である．地 表面の影響としては (i) 紐かな凹凸による地表面反射 
の変動と (ii) 傾斜による空気層の厚さの変動がもたら す速度場の不均質性ができ, 地中イメージの計算機上 での結像時に歪みが生じることが挙げられる.これら を抑制することを目的として，我々は3つのアンテナ を有するベクトル型地中レーダ(10)(11)（以下単にベク トルレーダと記述する）を地表面に倣い走查する方法 について研究を行ってきた ${ }^{(4) \sim(8)}$. アンテナ面を地表面 に倣い走査することでベクトルレーダのアンテナ面と 地表面が一定間隔で並行に向き合うことにより (i) 細 かな凹凸による地表面反射の影響を計算機上で軽隇で き, (ii) 空気層の厚みを一定に保つことで計算機上での 速度場が正確に求められる. しかし, 一方で migration 処理は断層計測などで主に用いられてきたため計測対 象の位置が十分に樑い場合には無視できるようなアン テナの位置誤差については論じられておらず, 墚度の 浅い部分を電磁波で計測するためにはアンテナの位置 も考慮に入れる必要がある. 特に地形適応走查はべク トルアンテナの高さ, 姿勢をマニピュレータによって 走査中に変動させるため影響が大きく, 問題となる.

本論文では，凹凸を有する地表面での地中埋設物探 查に打ける地形適応走查の必要性を述べ, 地中埋設物 の明確な像を得るためのベクトルレーダの特徵を考慮 した pre-stack migration を拡張した信号処理手法を提 案し, 実機実験により有効性を確認する.

\section{2. 地中レーダと信号処理}

本章では, 以降の議論の基本となる地中レーダの原 理とその信号処理の概要について述べる.

$2 \cdot 1$ 地中レーダの原理地中レーダ (Ground Penetrating Radar : GPR) とは, 送信アンテナによって 電磁波を地中に発射し, 地下の反射体からの反射波を受 信アンテナで受信, 受信信号の時間的な変化から地下 の構造を推定するセンサである. GPR には common source, common receiver, common midpoint, common offset などいくつかの計測法があるが(9), 本論では後 述するべクトルレーダによる common offset 計測を対 象とする.

GPR の計測結果は, 時間変動をそのままグラフと して表示するよりも, 時間変動を色付して表し横方向 に並べた時間断面や，後述する信号処理により空間的 な反射強度の分布を求め, これを断面やボリュームレ ンダリングといった形で表示することが多い( ${ }^{(9)}$. 本論 文では, 埋設物を容易に判別可能な空間的反射強度分 布を求めることを目的とする. 表示形態としては, 時 間断面, 水平断面, 垂直断面を適宜使い分ける.

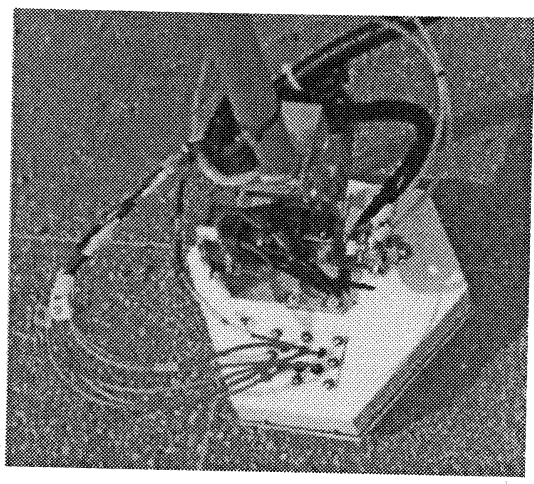

Fig. 1 Appearance of vector radar

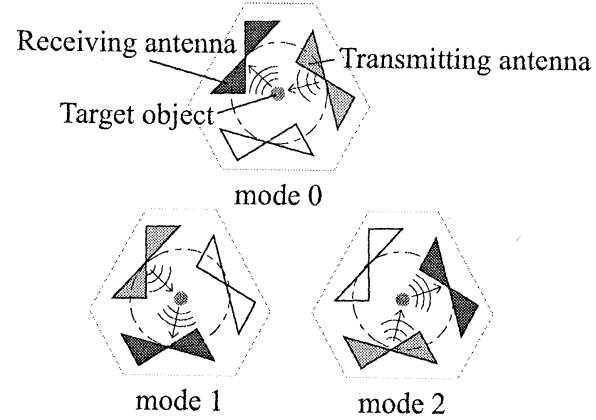

Fig. 2 Transmission mode of vector radar

$2 \cdot 2$ 地中レーダの信号処理 地中レーダの信号処 理はいくつかの段階を踏んで行われる. まず，地表面 からの反射や送受信アンテナ間のカップリングを平均 信号減算などの方法で除去する．この処理で地中の埋 設物からの信号が強調された信号は, デコンボリュー ション, 散乱行列処理, 逆フーリエ変換, ゼロ時間調 整, NMO 補正, migration, ゲインリカバリーなどの 処理を経て 3 次元的な反射率の空間分布を表す地下 の画像へと変換される.このうち, migration 処理は, ベクトルレーダによる地形適応走查時には特別な配慮 が必要である. 本論文ではこのための方法について論 ずる.

$2 \cdot 3$ 本論文で対象とするレーダシステム 本論 文では, ベクトル型地中レーダを使用する．このレー ダの写真を図 1 に示す.このレーダは, 3 つのアンテ ナエレメントを有し一回の計測時に, 図 2 に示すよう に3つの送受信アンテナの組合せで計測を行う。これ により送受信アンテナの組合せに並行な方向の像が強 調された計測信号が得られる.これを偏波モード呼び, 本論文で用いるべクトルレーダは 3 組の偏波モードの 信号から任意の方向が強調された信号を生成できると 


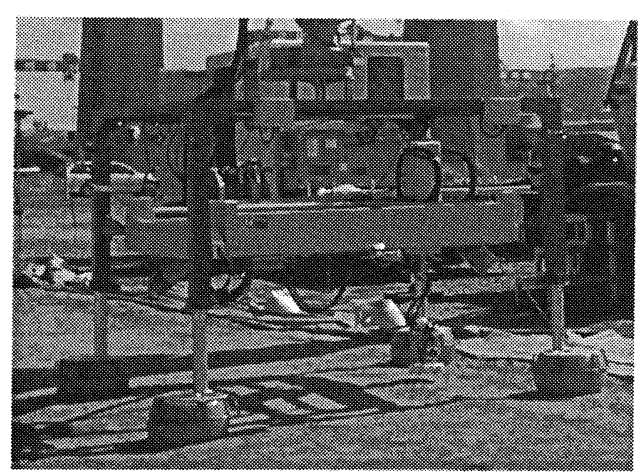

Fig. 3 Appearance of manipulation system

いう特徴を有する。それぞれの送受信アンテナ対で取 得された計測信号に散乱行列処理を加えることで, 任 意の送受信偏波角での計測信号を計算することができ る. ${ }^{(10)(11)}$.このレーダのセンサヘッドを, 図3に示す 6軸マニピュレータによって, 地表面に做うように2 次 元的に走查し，一定間隔ごとに計測を行う．これは小 菅らの研究グループが開発したマニピュレーション法 である(5)(7). データセットとしては, $\phi_{v}\left(x, y, z,{ }_{S}^{B} R, m, t\right)$ であらわされる反射波の場が計測されることになる. ここに, $[x, y, z]^{\top},{ }_{S}^{B} R$ は計測点でのセンサヘッド中心座 標およびセンサヘッドフレームの回転行列, $m$ は偏波 モード, $t$ は電磁波が送信アンテナから放出されてか ら受信アンテナで受信されるまでの時間である. ただ し, $z,{ }_{S}^{B} R$ は地表面形状から決まる $x, y$ の関数によって 拘束される.

$$
\begin{gathered}
z=z_{g}(x, y) \\
{ }_{S}^{B} R={ }_{S}^{B} R_{g}(x, y)
\end{gathered}
$$

よって引数として支配変数だけを残すと, ベクトル レーダの計測信号は $\phi_{v}(x, y, m, t)$ となる.

また, 本論文で使用したレーダは広帯域ステップ 周波数型レーダであり, 計測は時間領域ではなく 周波数領域で行われる. つまり, 本来の計測信号は $\psi_{v}\left(x, y, z,{ }_{S}^{B} R, m, f\right)$ で表される周波数域の信号である. 時間領域の計測信号は逆 Fourier 変換を用いて計算で きる。

$$
\begin{aligned}
\phi_{v}\left(x, y, z,{ }_{S}^{B} R, m, t\right) & =\operatorname{IFT}_{f}\left\{\psi_{v}\left(x, y, z,{ }_{S}^{B} R, m, f\right)\right\} \\
& =\frac{1}{\sqrt{2 \pi}} \int_{-\infty}^{\infty} \psi_{v}\left(x, y, z,{ }_{S}^{B} R, m, f\right) e^{j 2 \pi f t} d f
\end{aligned}
$$

\section{3. 時間領域地形適応 migration}

通常, レーダ計測においては地表面上を走査するこ とで信号の空間的な分布 $\phi(x, y, t)$ を求める. しかし,
地中レーダのアンテナは通常それほど空間的な指向性 が強くないため, ある空間座標 $\mathbf{p}_{o}=\left(x_{o}, y_{o}, z_{o}\right)$ に体積 が十分小さい反射体があるとき，その影響は観測信号 $\phi(x, y, t)$ 中に空間的広がりをもってあらわれる.つま り, 反射波を単に距離に変換するだけでは, 空間的な 分解能が低い像しか得られない.

レーダ計測で得られる $(\mathrm{x}, \mathrm{y}, \mathrm{t})$ に対する信号から, 空間的な座標 $(\mathrm{x}, \mathrm{y}, \mathrm{z})$ に対する信号を求める処理が, migration(マイグレーション)である. migration は, 波 動伝播モデルに基づく一種の画像再構成手法で, 人工 地震による地下探査の分野で 1970 年代から活発に研 究されてきた ${ }^{(13)}$.また, 電磁波レーダに対しては, 人 工衛星や航空機の合成開口レーダとして広く知られて いる(14).

3.1 Kirchoff migration はじめに, 同一点で送 受信を行うレーダで平面計測を行う場合を考える.す なわち

$$
\begin{array}{r}
z_{g}(x, y)=0 \\
{ }_{S}^{B} R_{g}=I_{3}
\end{array}
$$

の場合である.

アンテナの座標を $\mathbf{p}_{S}=\left[x_{S}, y_{S}, 0\right]^{\top}$, 反射体の座標を $\mathbf{p}_{o}=[x, y, z]$, 送信波を $h(t)$ とすると, 時間領域の受信 信号 $\phi\left(x_{S}, y_{S}, t\right)$ は,

$$
\phi\left(x_{S}, y_{S}, t\right)=h\left(t-\frac{2 \sqrt{\left(x-x_{S}\right)^{2}+\left(y-y_{S}\right)^{2}+z^{2}}}{v}\right)
$$

となる.ここで, $v$ は電磁波の伝播速度であり, 観測 領域中で一定と仮定する，送信波としてディラック のデルタ関数 $\delta(t)$ を考えると, 観測信号場は, $t=$ $2\left\|\mathbf{p}_{S}-\mathbf{p}_{o}\right\| / v$ で無限大, それ以外で 0 となる.これ は, レーダの計測データには, 座標 $\mathbf{p}_{o}$ にある点状の 反射体が双曲面状のエネルギー分布をもって観測され ることを意味している. migrationでは, この双曲面状 に広がった信号を元に戻すため，以下の式を用いる．

$$
\begin{aligned}
\sigma(x, y, z) & =\frac{1}{2 \pi} \iint \frac{\cos \theta}{r^{2}} \phi\left(x_{S}, y_{S}, t_{p}\right) d x_{S} d y_{S} \\
r & =\sqrt{\left(x-x_{S}\right)^{2}+\left(y-y_{S}\right)^{2}+z^{2}} \\
\cos \theta & =-z / r \\
t_{p} & =2 r / v
\end{aligned}
$$

ここで, $\sigma(x, y, z)$ は座標 $[x, y, z]^{\top}$ における再構成され た信号の振幅である. 式(7)は Kirchoff 積分と呼ばれ, 時間領域での migrationの基本となる式である.この 計算は, 双曲面上に広がった点 $(x, y, z)$ の影響を集め, 平均化することで $(x, y, z)$ での反射率を復元するもの である. すなわち, もし点状の反射体が座標 $(x, y, z)$ に 
存在したときに観測されるであろう信号と, 実際の信 号との相関をとることに相当する ${ }^{(12)}$. (波動方程式か らの導出は文献 ${ }^{(13)}$ を参照)

3.2 ベクトルレーダによる地形適応走査時の migration 前節の Kirchoff migration は, 平坦走査 ${ }^{1}$ を仮定している.このままでは, 地形適応走査による データセットに適用できない，そこで, 地形適応走查 を考慮した Kirchoff migration（地形適応 migration）が 考案された. また, アンテナと埋設物との距離が比較 的小さいときには, 式(7)で無視しているアンテナ間距 離の影響が無視できない. そこで, pre-stack migration という手法を応用することでこの問題を解決する.

ただし，これらの手法を単独で用いても，よい結果 を得ることはできない. 本論文では, 地形適応 Kirchoff migration と Pre-stack Kirchoff migration の考え方を組 み合わせ, ベクトルレーダに拡張した migration の手 法を提案する.

3.2.1 地形適応 Kirchoff migration 前節の Kirchoff migration は送受信が地表面 $z_{g}(x, y)=0$ で行 われたと仮定している. 地形適応走査を行った際には, センサ高さまで考慮して式(7)を計算する(7)(6).

$$
\begin{aligned}
\sigma(x, y, z) & =\frac{1}{2 \pi} \iint \frac{\cos \theta}{r^{2}} \phi\left(x_{S}, y_{S}, t_{p}\right) d x_{S} d y_{S} \\
\mathbf{p} & =[x, y, z]^{\top}, \mathbf{p}_{S}=\left[x_{S}, y_{S}, z_{g}\left(x_{S}, y_{S}\right)\right]^{\top} \\
r & =\left\|\mathbf{p}_{S}-\mathbf{p}\right\| \\
\cos \theta & =\mathbf{n}_{g}\left(x_{S}, y_{S}\right) \cdot\left(\mathbf{p}_{S}-\mathbf{p}\right) / r \\
t_{p} & =2 r / v
\end{aligned}
$$

ここで, $\mathbf{n}_{g}(x, y)$ は地表面 $z_{g}(x, y)$ の上向き単位法線べ クトルであり, センサヘッド姿勢をあらわす回転行列 ${ }_{S}^{B} R$ とは以下の関係にある.

$$
\mathbf{n}_{g}(x, y)={ }_{S}^{B} R(x, y) \cdot[0,0,1]^{\top}
$$

これらの式は, 指向性係数 $\cos \theta$ と伝播時間 $t_{p}$ の計算 に, センサヘッド高さおよび姿勢の影響を織り込んで いる.

\section{2 .2 ベクトルレーダによる地形適応走查時の} Kirchoff migration 前節までの migration は, 送 信と受信が同じ座標で行われるという仮定に基づい ている. 我々が本論文で用いている地中レーダは, 送 信アンテナと受信アンテナが異なり，実際に用いられ るレーダもそのようなものが多い.このようなレーダ では, 電磁波の伝播時間と埋設物の梁さは比例関係に ない.

\footnotetext{
1本論文での平坦走査とは地表面形状に関係なくレーダアンテナ 面を水平方向に合わせて, 高さを一定に保ったままでレーダアンテ ナを走査する作業を指す。
}

深さ $d$ の埋設物を, その真上に置いたアンテナ間距 離 $h$ のレーダで観測したとき, この埋設物で反射され る電磁波の伝播時間 $t_{p}$ は,

$$
t_{p}=\frac{2}{v} \sqrt{d^{2}+(h / 2)^{2}}=\frac{2}{v} d \sqrt{1+\left(\frac{h / 2}{d}\right)^{2}}
$$

となる ${ }^{(15)}$.この問題を回避するため, 通常は図 4 に示 すように，送受信アンテナ間に仮想的なアンテナを置 き,このアンテナで送受信を行ったと仮定したときの 時系列信号 $\bar{\phi}\left(\overline{t_{p}}\right)=\phi\left(\hat{t_{p}}\right)$ を求め, $\bar{\phi}$ を使って式 (7)の migration を行う(3). ここで, 仮想アンテナの伝播時間

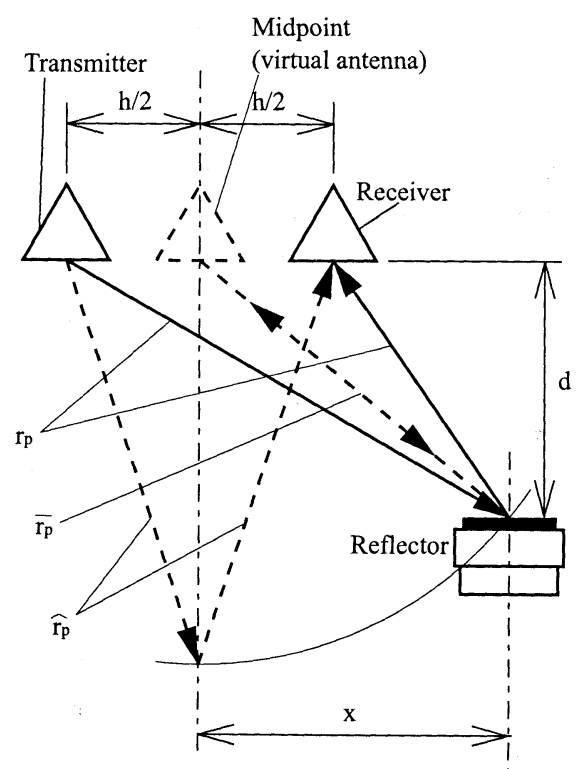

Fig. 4 Geometries of Antennae and reflector for NMO correction

$\overline{t_{p}}$ から，それに相当する実際の伝播時間 $\hat{t}_{p}$ を求めるの に, 式(17) を基にした NMO 補正（Normal MoveOut correction）を用いる.

$$
\begin{aligned}
\hat{t_{p}}=\frac{\hat{r_{p}}}{v} & =\frac{2}{v} \sqrt{\left(\overline{r_{p}} / 2\right)^{2}+(h / 2)^{2}} \\
& =\frac{2}{v} \sqrt{\left(\overline{t_{p}} v / 2\right)^{2}+(h / 2)^{2}}
\end{aligned}
$$

ただし， $r_{p}$ は NMO 補正によって計算された往復の伝 播距離, $\overline{r_{p}}$ は仮想アンテナからの往復の伝播距離で ある.

図 5 は, 計測点と埋設物との水平方向の相対距離 $x$ に対する $\hat{r_{p}}$ と実際の伝播距離 $r_{p}$ の関係を表す. 值 は $h / 2$ で正規化してある. このグラフから分かるよう に, $x=0$ のとき $\hat{r_{p}}$ と $r_{p}$ は当然ながら完全に一致する $\left(\because \overline{r_{p}}=2 d\right)$ が, $x \neq 0$ のときは一致しない. この効 


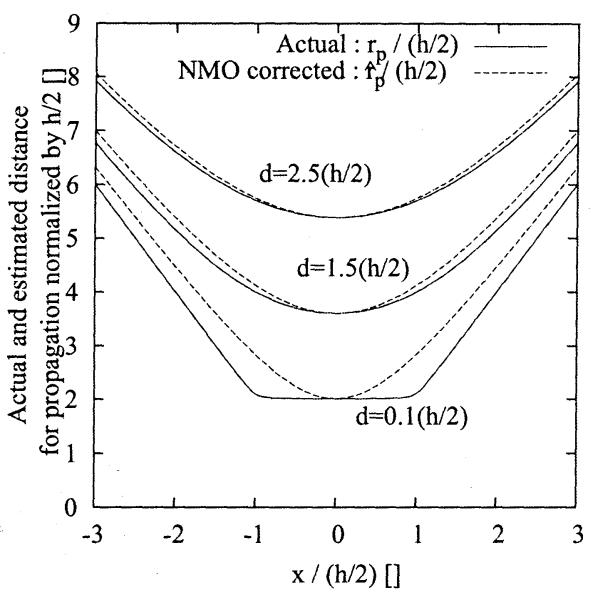

Fig. 5 Distances for propagation

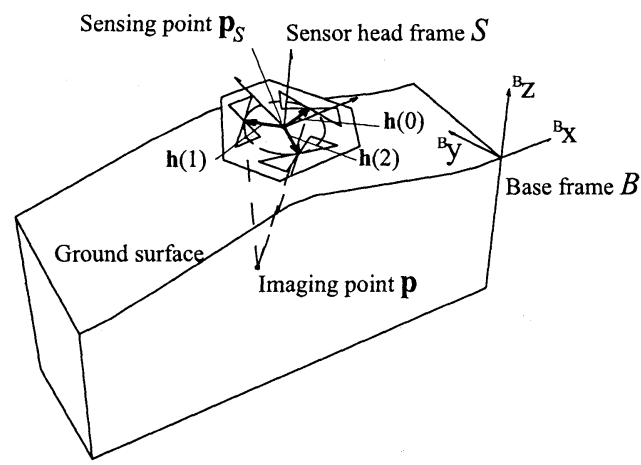

Fig. 6 Alignment of the sensor and an imaging point

果は埋設物がアンテナ対に近いときに顕著であり,イ メージング精度の悪化を招く. そこで, migration 中に 同時にスタックを行う（Stacking with Migration）方法 が編み出された.これを pre-stack migration という ${ }^{(3)}$. pre-stack migration では電磁波が注目する地中の点を 通り受信アンテナに到達するまでの時間を忠実に織り 込むように計算する．この手法により，上に挙げたよ うな問題を回避して高精度なイメージを得る事ができ ることが知られている(3). 地雷のように小さく, 計測 位置の近くに存在する埋設物をイメージングするため には, pre-stack migration が適している.

それに対して我々は地形適応 migration と pre-stack migration と同様に伝播時間を正確に求める手法を, ベ クトルレーダによる地形適応走査に対する migration に対して実現するために, アンテナ配置と計測時のア ンテナ姿勢から直接往復の伝播時間を求める.

図 6 に示すように, 注目する地中の座標を $\mathrm{p}=$

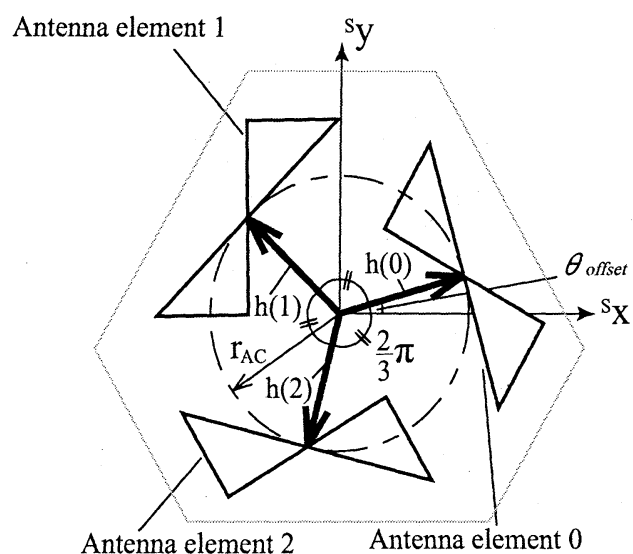

Fig. 7 Alignment of antenna elements

$[x, y, z]^{\top}$, 計測点でのセンサヘッド中心の位置を $\mathbf{p}_{S}=$ $\left[x_{S}, y_{S}, z_{g}\left(x_{S}, y_{S}\right)\right]^{\top}$ とすると，

$$
\begin{aligned}
\sigma(x, y, z) & =\sum_{m=0}^{2} \iint_{-\infty}^{\infty} \frac{\cos \theta}{r^{2}} \phi_{v}\left(x_{S}, y_{S}, m, t_{p}\right) d x_{S} d y_{S} \\
r & =\left\|\mathbf{p}_{S}-\mathbf{p}\right\| \\
\cos \theta & =\mathbf{n}_{g}\left(x_{S}, y_{S}\right) \cdot\left(\mathbf{p}_{S}-\mathbf{p}\right) / r
\end{aligned}
$$

ただし $t_{p}$ は電磁波の伝播時間で,

$$
\begin{aligned}
t_{p} & =\left(\left\|\mathbf{p}_{T}-\mathbf{p}\right\|+\left\|\mathbf{p}_{R}-\mathbf{p}\right\|\right) / v \\
\mathbf{p}_{T} & =\mathbf{p}_{S}+{ }_{S}^{B} R\left(\mathbf{p}_{S}\right)^{S} \mathbf{h}\left(i_{T}(m)\right) \\
\mathbf{p}_{R} & =\mathbf{p}_{S}+{ }_{S}^{B} R\left(\mathbf{p}_{S}\right)^{S} \mathbf{h}\left(i_{R}(m)\right)
\end{aligned}
$$

によって計算される.

$i_{T}(m)$ および $i_{R}(m)$ は，偏波モード $m$ の信号を取得 するのに使用する送受信アンテナエレメントの番号で あり,

$$
\begin{aligned}
& i_{T}(m)=m \\
& i_{R}(m)=(m+1) \bmod 3
\end{aligned}
$$

によって決定される. また, ${ }_{S}^{B} R\left(\mathbf{p}_{S}\right)$ は計測点 $\mathbf{p}_{S} に お ~$ けるセンサヘッドフレーム $\{S\}$ の基準フレーム $\{B\}$ に 対する回転行列, ${ }^{S} \mathbf{h}(i)$ は $i$ 番目のアンテナエレメント の $\{S\}$ からみた位置であり, 図7 から分かるように, 次式で計算される.

$$
S_{\mathbf{h}(i)}=\left[\begin{array}{c}
r_{A C} \cos \left(\frac{2 \pi}{3} i+\theta_{\text {offset }}\right) \\
r_{A C} \sin \left(\frac{2 \pi}{3} i+\theta_{o f f s e t}\right) \\
0
\end{array}\right]
$$

ここで, $r_{A C}$ はアンテナが位置する円の半径である.

以上の式は以下のような意味を持つ. 注目する地中 の座標 $\mathbf{p}$ が, 計測点 $\mathbf{p}_{S}$ での3 つの偏波モードの信号に 


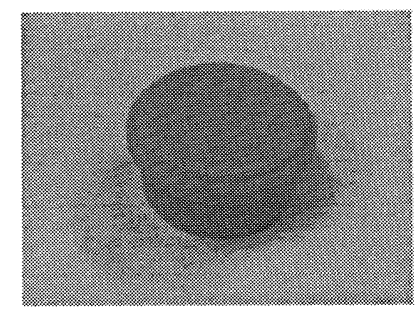

Fig. 8 Type72 landmine model

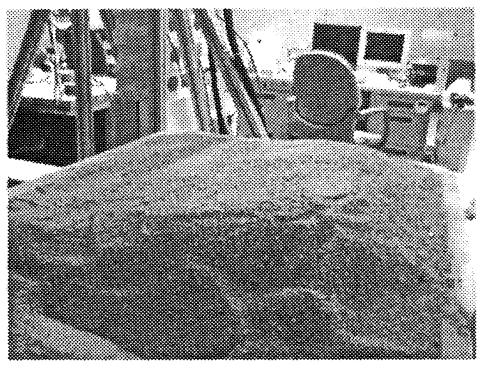

Fig. 9 The sand tank used for the experiment

影響を与えた時刻を，アンテナの位置を正確に織り込 んで計算し，その時刻における信号強度に指向性と伝 播距離に由来する強度補正を加えつつ足し合わせてい る. 各偏波モードの信号を平均的に加算するのは, 散乱 行列のトレース，すなわち等方的な反射成分を抽出す ることに相当する ${ }^{(10)}$ ため, 式(19)によって migration と偏波処理を同時に行っている (Polar Processing with Migration）と捉えることもできる.

\section{4. 実データへの適用}

4 -1 実験環境提案した手法の有効性を確認す るため, ベクトルレーダによる模擬地雷の計測実験を 行った.

使用した埋設物は, 中国製 Type 72 対人地雷を模し たプラスチック製の模型 $(\phi 78[\mathrm{~mm}] \times 40[\mathrm{~mm}])$ である. 外観を図 8 に示す.

屋内の土槽に乾燥した砂（含水率 $3 \%$ ）を詰め, 地 表面を斜面状に整形し，この模擬地雷を水平かつ上面 が地表面と同じ高さになるように埋設した. 図 9 に模 擬地雷埋設後の実験土槽を, 図 10 にレーザー距離計 によって得られた計測領域の地表面形状を示す。

4.2 地形適応走査と平坦走査の違い まず地形 適応走査自体の有効性を示す. 平坦走查および適応走 査をかけて得られた地中レーダの信号に, 式(19)によ る時間領域 migrationを行う. 得られた結果を水平断 面として図 11 に示す. 図 11(a) が平坦走查, 図 11(b)

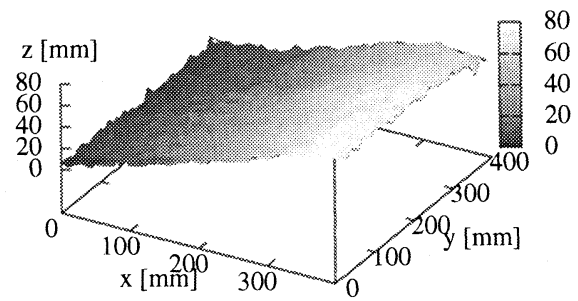

Fig. 10 The shape of the ground surface

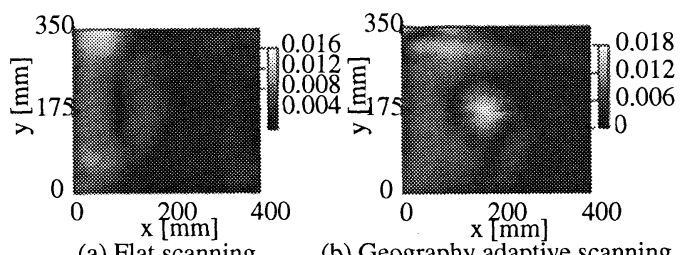

(a) Flat scanning

(b) Geography adaptive scanning

Fig. 11 Horizontal slices reconstructed from the signals acquired by level scanning and geography adaptive scanning

が適応走査の結果である. 平坦走査の結果 (a)におい ては埋設物の判別が難しいのに対して, 地形適応走查 の結果 (b) では, 埋設物の丸い形状が正しく捉えられ ていることが分かる.

4.3 ベクトルレーダによる偏波処理の効果 次 に, ベクトルレーダで得られる 3 つの偏波モードの信 号を重ね合わせることの効果を示す. 図 12 は地形適応 走査して得られた信号に提案手法で migration を行った 結果である.ただし，図 12(a)〜 (c) はそれぞれ式 (19) 外側の $m$ に関する和をとらず, 単一の偏波モードのみ を使って migration を行った結果であり, 図 12(d) は式 (19)をすべて計算し，3つの偏波モードを統合して得 られた結果である. 結果はすべて埋設深度の水平断面 である。

単一偏波モードのみを使用した場合でも，埋設物の 位置 ((200[mm],175[mm]) 付近) は確認できるが, 埋 設状態の偏波特性によるとみられる反応の変形が見ら れる. また，目標とする埋設物以外の反応であるクラッ タがやや目立つ結果になっている. 特に $m=2$ におい て顕著であり, 画面上方のクラッタの方が埋設物より も強い反応を示している：これに対して，3つの偏波 モードを統合した場合は, より埋設物にフォーカスし た，埋設物の丸い形状がはっきりと分かる像が得られ ている. さらに, クラッタも単一偏波モードの場合よ りも抑えられている. 


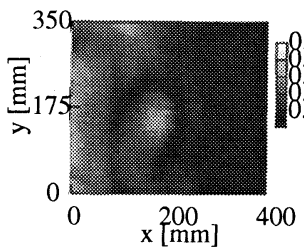

(a) $m=0$

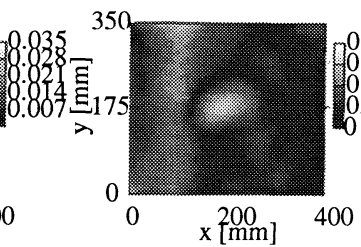

(b) $m=1$

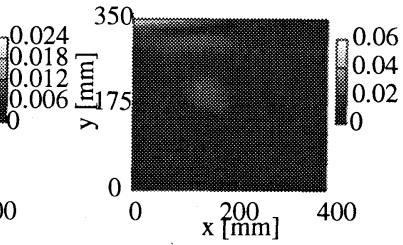

(c) $m=2$

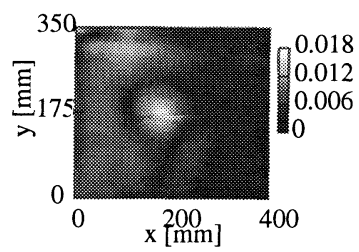

(d) Synthesized

Fig. 12 Horizontal slices processed with various polar modes

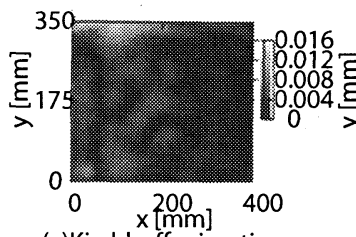

(a)Kirchhoff migration with NMO correction

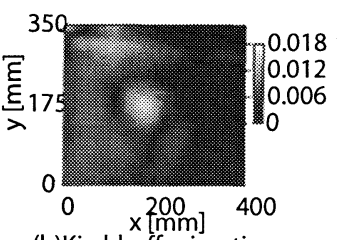

(b) Kirchhoff migration modified for vector radar

Fig. 13 Holizontal slices processed with and without consideration of the alignment of antennas in the sensor head

4.4 ベクトルレーダに拡張した migration と通常の migration の違い 提案手法によりアンテナの配置 を適切に織り込んで計算することで, 正確な地中の像 が得られることを示す.

センサヘッド中心点ですべて偏波モードの送受信が 行われたと仮定して migration を行った結果を図 13(a) に（3つの偏波モードそれぞれに対して式 (11)でマイ グレーションを行い加算），提案手法で migration を 行った結果を図 13(b) に示す. それぞれ埋設深度の水 平断面である.

提案手法で処理した結果では，クリアな像が得られ ているが，同一送受信点仮定の結果では，3偏波モ一 ドの信号を足し合わせても，アンテナ位置のずれの影 響が出て反応が分散し, 判別可能なほど強い反忍は得 られないことが分かる.

\section{5. おわりに}

本論文では, pre-stack migration をベクトルレーダ による地形適灾走查に拡張して適用し，平面でない地 形において地表面付近に模擬地雷が埋設されている場 合に, 明瞭な対象物の像を得ることができることを示 した.

今後は, 地形適応の度合を変化させたときにイメー ジングの結果がどのように変化するかを調査したいと 考えている. また，計算時間とイメージの精度を両立す

るため, 計算量が少ないことで知られる $\mathrm{f}-\mathrm{k}$ migration のベクトルレーダによる地形適応走査への応用もあわ せて検討していく予定である。

\section{謝辞}

本研究は科学技術振興機構の研究開発プロジェクト 「人道的観点からの対人地雷の地雷探知・除去活動を 支援するセンシング技術，アクセス・制御技術の研究 開発」の一部として行われた．実験に用いたレーダは 三井造船株式会社によって開発され，提供して頂いた ものである.また, 時間領域の migration に必要なパラ メータ（距離減衰補正係数, 開口角および指向性補正 係数）を決定する際に, 東北大学の藪下博士が作成さ れた信号処理のプログラムを参考にさせて頂いた.

ここに謝意を表する.

\section{文献}

(1) Shimoi, N., Technology for detecting and clearing LANDMINES, Morikita Shuppan Co., Ltd., (2002), pp.43, pp.66-81.

(2) Geneve International Centre for Humanitarian Demining, A Guide to Mine Action, http://www.gichd.ch/96.0.html, pp.63-77.

(3) Feng, X., Sato, M., Pre-stack migration applied to GPR for landmine detection, "Inverse Problems", 20, (2004), pp.99-115.

(4) Fukuda, T. et al., Land mine detection algorithm using Ultra Wide Band GPR, "Proceedings of the first International Symposium on Systems \& Human Science", (2003), pp.295-300.

(5) Yabushita, H. et al, A small Reaction Manipulator for Maneuvering a GPR Sensing Head, "Systems \& Human Science - For Safety, Security, and Dependability; Selected Papers of the 1st International Symposium SSR2003, Osaka, Japan, November 2003",Elsevier Science Ltd, (2005), pp.245-257.

(6) HASEGAWA, Y. et al., Landmine Detection Algorithm using UWB GPR, "SICE System Integration Division Anuual Conference (SI2004)", (2004), pp.1033-1034.

(7) Yabushita, H. et al., Ground Adaptive Manipulation of GPR and Image Reconstruction for Landmine Detection, "SICE System Integration Division Anuual Conference (SI2004)", (2004), pp.1029-1030. 
(8) Hasegawa, Y. et al., Automatic Extraction for Mine Suspects from GPR, "Proc. of the IARP International workshop on Robotics and Mechanical Assistance in Humanitarian Demining", (2005), pp.27-32.

(9) Daniels, D. J., Ground Penetrating Radar 2nd Edition, The Institution of Electrical Engineers, (2004), pp.278292.

(10) Kimura, N. et al., Development of Radar for Investigation of Buried Objects (First Report), "National Convention of the Institute of Electrical Engineers of Japan 1992", (1992), pp.P1-64-P1-65.

(11) Murasawa, K. et al., Development of Radar for Investigation of Buried Objects (Second Report), "National Convention of the Institute of Electrical Engineers of Japan 1992", (1992), pp.P1-66-P1-67.

(12) Sato, M. et al., Subsurface Investigation with Electromagnetic Wave, The textbook for public recurrent education named "Subsurface Investigation with Electromagnetic Wave" held in Tohoku Univ., (2004), pp.93.

(13) Schneider, W. A., Integral Formulation for Migration in Two and Three Dimensions, "Geophysics", Vol.43, No.1, (1978), pp.49-76.

(14) Milman, A. S., SAR imaging by $\omega-k$ migration, "International Journal of Remote Sensing", Vol.14, No.10, (1993), pp.1965-1979.

(15) Sato, M., Subsurface Imaging by Ground Penetrating Radar, "IEICE Transcations", , Vol.J85-C, No.7, (2002), pp.520-530. 